\title{
Artykuey
}

KLIO. Czasopismo poświęcone dziejom Polski i powszechnym

PL ISSN 1643-8191, t. 21 (2) 2012, s. 57-76

\author{
Justyna Budzińska
}

(Poznań)

\section{Mit, stereotyp i fantazmat - między szablonem a inną wizja przeszłości w szkolnym kursie historii (przypadek ikonografii)}

\section{W świetle definicji i dokumentów...}

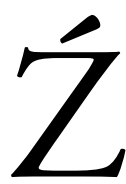

ródła ikonograficzne, źródła obrazowe, ikonografia, obraz, przedstawienie - to w zasadzie pojęcia synonimiczne, jeżeli chodzi o ich aspekt „użytkowy” w odniesieniu do praktyki szkolnej, jakkolwiek w praktyce badawczej każde z nich jest obarczone nieco innym znaczeniem ${ }^{1}$. Dla naszych dalszych rozważań, podejmujących zagadnienie wykorzystania w szkolnym (a dokładniej ponadgimnazjalnym) kursie historii przedstawień określonego typu, proponuję przyjąć założenie, że określenia te będziemy stosować zamiennie, rozumiejąc je jednak w sposób analogiczny (i zarazem

${ }^{1}$ Jak choćby pojęcie „ikonografii”, którą możemy rozumieć dwojako: jako naukę pomocniczą historii sztuki, której podstawową funkcją jest rozpoznanie i klasyfikacja tematów ikonograficznych, badanie ich stałości i powstawania wariantów ikonograficznych oraz motywów, a także deszyfracja treści symboli, personifikacji i atrybutów, co w konsekwencji prowadzi do ustalenia datowania lub autentyczności dzieł sztuki. Drugie znaczenie słowa „ikonografia” dotyczy określanego tym mianem zbioru dzieł sztuki, głównie malarstwa i fotografii, stanowiącego dokumentację danego tematu, osoby, miejsca lub zagadnienia; możemy zatem mówić o ikonografii Napoleona, ikonografii Krakowa, ikonografii wczesnochrześcijańskiej itd. Por. Stownik terminologiczny sztuk pięknych, red. K. Kubalska-Sulkiewicz, M. Bielska-Łach, A. Manteuffel-Szarota, Warszawa 1996, s. 157. 
szeroki) jako przedmioty materialne wraz z przedstawieniem obrazowym na nich umieszczonym, z zaznaczeniem jednak, że funkcję dostarczyciela istotnych pod względem badawczym informacji pełni bądź samo przedstawienie, bądź w niektórych przypadkach także jego materialna podstawa. Inaczej - źródłem obrazowym będzie każde źródło „zapisane obrazem” (zgodnie z etymologią słowa „ikonograficzne”)2. Podobnie definiowane są źródła ikonograficzne w biuletynie maturalnym z historii, gdzie, występując wśród innych źródeł wiedzy ucznia, określane są (zamiennie) jako „obrazy”, „materiały ikonograficzne” bądź „,reprodukcje” obrazów, rycin, karykatur, rysunków satyrycznych, fotografii, zabytków architektonicznych ${ }^{3}$ oraz - co można stwierdzić na podstawie analizy arkuszy egzaminacyjnych - rzeźb i/lub płaskorzeźb. Tzw. zadania z wyposażeniem, a więc z wykorzystaniem różnych źródeł informacji (a więc, obok ikonografii, również tekstów źródłowych, map, danych statystycznych (diagramy, tabele), źródeł/ tablic genealogicznych) są elementem testów maturalnych zarówno na poziomie podstawowym (test zawierający zadania zamknięte i otwarte), jak i rozszerzonym (test jak na poziomie podstawowym, praca z materiałem źródłowym i wypracowanie). Sposoby rozwiązywania zadań z wyposażeniem, a więc sposoby wykorzystania materiałów źródłowych, ufundowane

2 Takie rozumienie „źródła ikonograficznego” zaproponował m.in. K. M. Kowalski, definiując je jako szczególny przypadek źródła historycznego, wyróżniający się specyficznym (obrazowym) kodem informacyjnym. Por. idem, Polskie źródta ikonograficzne XVII wieku, Warszawa-Poznań 1988, s. 25. Natomiast wspomniane pojęcie „przedstawienia” pojawia się w tych definicjach, które źródło ikonograficzne traktują jako tożsame właśnie z samym przedstawieniem. Takie definicje określają nasz rodzaj źródła jako np. każde przedstawienie plastyczne wykonane $w$ różnych technikach rzeźbiarskich, malarskich, rysunkowych, zdobniczych i graficznych, niezależnie od tego, jakie przedstawia ono wartości artystyczne czy cele techniczne, byle bytoby zwiazane tematycznie z jakaśs dziedzina produkcji czy konsumpcji (por. I. Turnau, Źródta ikonograficzne do nowożytnej historii produkcji i konsumpcji. Próba klasyfikacji, „Kwartalnik Historii Kultury Materialnej”, R. XIV, 1966, nr 1, s. 51; cyt. za K. M. Kowalski, Polskie źródta..., s. 19), jako każde przedstawienie plastyczne, które będąc przedmiotem krytyki źródłowej i analizy ikonograficznej dostarczy informacji na żadany temat (por. G. Skalski, Dokumentacja ikonograficzna w etnografii, „Lud”, t. LX, 1976, s. 83; cyt. za K. M. Kowalski, Polskie źródta..., s. 19) bądź też jako catość przekazów przedstawiających, spetniających ogólne cechy źródła naukowego. [...] zarówno rzeźba, jak i obraz, rysunek czy fotografia i film (por. B. Jewsiewicki, Próba zasygnalizowania roli źródta ikonograficznego w badaniach etnograficznych, „Etnografia Polska”, t. VIII, 1964, s. 251-263; cyt. za: K. M. Kowalski, Polskie źródta..., s. 19).

3 Biuletyn maturalny nr 5. Historia, Wydział Matur CKE, 2004, s. 5, 11-12, wersja elektroniczna: http://www.cke.edu.pl/images/stories/BIULETYNY_MATURALNE/biuletyn_5_historia.pdf (dostęp: 31.04.2012). 
są na standardach wymagań egzaminacyjnych (a więc schierarchizowanym zestawieniu umiejętności, jakimi powinien dysponować przystępujący do egzaminu maturalnego absolwent szkoły ponadgimnazjalnej) oraz na nowej podstawie programowej, która weszła w życie 1 września 2009 i zawiera również standardy, którym uprzednio poświęcone było osobne rozporządzenie. Do źródeł informacji odnoszą się następujące standardy ${ }^{4}$ zawarte w dotychczasowym rozporządzeniu (kursywą zaznaczono kluczowe czasowniki operacyjne, wskazujące na konkretną czynność dokonywaną na materiale źródłowym):

a) Poziom podstawowy:

Obszar II - korzystanie z informacji (Zdający stosuje faktografię i terminologię historyczną do wyjaśnienia procesu historycznego)

standard 7: korzysta z różnorodnych źródeł wiedzy historycznej - wyszukuje informacje:

- odczytuje informacje z różnorodnych źródeł wiedzy historycznej (np. tekst pisany, ilustracja, mapa, tablica genealogiczna, tabela statystyczna, wykres, diagram, schemat),

- wybiera informacje wyjaśniające problem,

- odróżnia fakty od opinii.

Obszar III - tworzenie informacji (Zdający przedstawia oraz ocenia wydarzenia i zjawiska historyczne, formułując przejrzystą i logiczną wypowiedź pisemna)

standard 1: porównuje, czyli wskazuje różnice i podobieństwa między wydarzeniami historycznymi:

- opisuje wydarzenia i zjawiska historyczne, uwzględniając zachodzące między nimi podobieństwa i różnice,

- porównuje wydarzenia, wskazując cechy charakterystyczne dla epok i okresów historycznych,

- wyciaga i przedstawia wnioski wynikające z porównania;

standard 2: formutuje oceny:

- formutuje własną ocenę na podstawie wybranych faktów;

standard 3: uzasadnia sformułowane oceny:

- dobiera argumenty niezbędne do uzasadnienia opinii.

${ }^{4}$ Rozporzadzenie Ministra Edukacji Narodowej z dnia 10 sierpnia 2001 r. w sprawie standardów wymagań będacych podstawa przeprowadzania sprawdzianów i egzaminów (Dz.U. Nr 92, poz. 1020 oraz z 2003 r. Nr 90, poz. 846, z późn. zm.). 
b) Poziom rozszerzony:

Obszar II $(\mathrm{j} / \mathrm{w})$ oraz standard 1: korzysta $\mathrm{z}$ różnorodnych źródeł wiedzy historycznej - wyszukuje i interpretuje informacje zgodnie z warsztatem historycznym:

- analizuje różnorodne źródła (tekstowe, ikonograficzne, kartograficzne, symboliczne) zgodnie z wymogami warsztatu historycznego,

- wykorzystuje uzyskane informacje do wyjaśnienia procesu historycznego,

- poddaje krytyce różnorodne źródła informacji,

- porównuje informacje i wartościuje je,

- podaje przykłady krytycznych interpretacji danego problemu;

Obszar III (j/w) oraz standard 2: krytycznie analizuje i ocenia różne interpretacje historii:

- dostrzega różne interpretacje historii i ich przyczyny,

- uwzględnia informacje oraz opinie różniące się między sobą,

- formutuje wnioski,

- ocenia wybrane problemy historyczne z uwzględnieniem zasad naukowego badania przeszłości.

Według nowej podstawy programowej kluczowe są następujące wymagania (wyszczególnione w ramach Celów ksztatcenia - wymagań ogólnych; są w zasadzie analogiczne dla poziomu podstawowego i rozszerzonego, z tą różnica, że w ramach Analizy i interpretacji historycznej dla poziomu podstawowego kluczowe jest odniesienie do kontekstu konkretnej epoki, natomiast dla poziomu rozszerzonego - innych epok $)^{5}$ :

a) poziom podstawowy:

\section{Analiza i interpretacja historyczna}

Uczeń analizuje wydarzenia, zjawiska i procesy historyczne w kontekście epoki/epok i dostrzega zależności pomiędzy różnymi dziedzinami życia społecznego; rozpoznaje rodzaje źródeł; ocenia przydatność źródła do wyjaśnienia problemu historycznego; dostrzega wielość perspektyw badawczych oraz wielorakie interpretacje historii i ich przyczyny.

5 Rozporzadzenie Ministra Edukacji Narodowej z dnia 23 grudnia 2008 r. w sprawie podstawy programowej wychowania przedszkolnego oraz kształcenia ogólnego w poszczególnych typach szkót, Załącznik nr 4 - Podstawa programowa ksztatcenia ogólnego dla gimnazjów i szkót ponadgimnazjalnych, których ukończenie umożliwia uzyskanie świadectwa dojrzałości po zdaniu egzaminu maturalnego (Dz.U. z 2009 r. Nr 4, poz. 17). 


\section{Tworzenie narracji historycznej}

Uczeń tworzy narrację historyczną w ujęciu przekrojowym lub problemowym; dostrzega problem i buduje argumentację, uwzględniając różne aspekty procesu historycznego; dokonuje selekcji i hierarchizacji oraz integruje pozyskane informacje z różnych źródeł wiedzy.

Wobec przytoczonych powyżej standardów szkoła ponadgimnazjalna, czyli trzeci, ostatni etap edukacji szkolnej, jawi się, na gruncie interesujących nas źródeł obrazowych jako etap „domykający” (jeśli chodzi o sposób pracy z obrazem), niejako spinający i kompletujący to, co nazwać można wytuskiwaniem informacji ze źródła. Po odpowiedzi na pytania: co? (opisowa funkcja źródeł w szkole podstawowej) oraz jak?, w jaki sposób? (funkcja analityczna w gimnazjum), etap ponadgimnazjalny to pora na pogłębioną analizę i interpretację, na samodzielną próbę nie tylko odpowiedzi na kolejne pytanie - dlaczego?, ale także na samodzielne dostrzeżenie potrzeby sformułowania takiego pytania. Innymi słowy - istota pracy z materiałem ikonograficznym powinna dążyć do tego, aby uczniowie przystępujący do egzaminu maturalnego $\mathrm{z}$ historii dysponowali m.in. dwiema istotnymi umiejętnościami:

- dostrzegania różnych interpretacji historii i ich przyczyn (a więc znajomości specyfiki poszczególnych rodzajów źródeł, realizującej się w różnych kodach/językach, jakimi źródła operuja),

- dokonywania integracji wiedzy o przeszłości czerpanej z różnych źródeł informacji oraz własnych doświadczeń, ocen i refleksji (czyli umiejętności, po pierwsze, dokonywania analizy porównawczej, i po drugie - wykorzystywania wiedzy pozaźródłowej, w tym własnej historycznej intuicji).

W świetle tych umiejętności konieczne staje się umieszczanie źródła obrazowego w roli jednego z przekazów dotyczących przeszłej rzeczywistości, którego/których główną funkcją będzie przede wszystkim umożliwienie szerokiego spojrzenia na rozpatrywane właśnie zagadnienie. Uczeń szkoły ponadgimnazjalnej, wyposażony na dwóch poprzednich etapach edukacyjnych w umiejętność dokładnego opisu i analizy źródła, powinien teraz podejmować samodzielne próby, z jednej strony, syntezy informacji (prowadzącej do odkodowania ukrytych poza warstwą widzialną treści) zawartych w przekazie ikonicznym, z drugiej zaś - syntezy informacji zaczerpniętych z innych źródeł informacji. Czyli najpierw - zrozumienie obrazu, a następnie - za- 
uważenie i zrozumienie sytuacji bardziej złożonej, ufundowanej na przesłankach pochodzących ze źródeł operujących innym językiem przekazu.

\section{... i w świetle obrazów.}

\section{Mit, stereotyp i fantazmat}

Gtówne motywy mitów sq te same i zawsze byty takie same. Jeśli chcesz stworzyć własna mitologię, sprawa zasadnicza jest to, z jaka społecznościa się wiążesz. Każda mitologia uksztaltowata się w pewnej spoteczności, w zamkniętym polu. [...] Mity trzeba utrzymywać przy życiu. Ludźmi, którzy moga to zrobić, sa wszelkiego rodzaju artyści. Funkcją artysty jest mitologizacja otoczenia i świata.

J. Campbell ${ }^{6}$

Jeśli na narrację obrazową/ikonografię spojrzymy jak na narrację pisaną i wyodrębnimy w niej, za Jerzym Topolskim ${ }^{7}$, trzy warstwy/przestrzenie interpretacyjne, okaże się, że w gruncie rzeczy do każdej z nich uczeń dociera na kolejnym etapie edukacyjnym.

Warstwa pierwsza, logiczno-gramatyczna, to główny nośnik informacji, a zarazem jedyna płaszczyzna w pełni artykułowana (pozostałe dwie mogą się ujawniać, choć nie musza), czyli dostępna od razu, w bezpośrednim oglądzie dzieła. Zawartość informacyjna (czyli rzeczowa) oraz ramy formalne wyznaczane elementami „logiczno-gramatycznymi” odnoszą się, najprościej rzecz ujmując, do tematu przedstawienia (przy czym nie chodzi tutaj o tytuł). Zostaje on zdefiniowany (zwizualizowany) przy użyciu reguł gramatycznych i logicznych obrazu - pewnych zasad, dyrektyw (stylowych, gatunkowych) oraz przestrzegania czegoś, co możemy określić jako wewnętrzną, treściową logiką narracji. W naszym przypadku tę pierwszą (choć przecież, w proce-

${ }^{6}$ J. Campbell, B. Moyers, Potęga mitu: rozmowy Billa Moyersa z Josephem Campbellem, oprac. B. S. Flowers, przekł. I. Kania, Kraków 1994, s. 49 i 140.

${ }^{7} \mathrm{~J}$. Topolski, Jak się pisze i rozumie historię. Tajemnice narracji historycznej, Warszawa 1996, s. 87-92. 
sie tworzenia ostatnią, skonstruowaną na bazie dwóch pozostałych), najbardziej zewnętrzną warstwę tworzyć będzie przedstawienie (wydarzenie, osoba, miejsce), które utrwalone zostało w obrazie. Aby tego dokonać, wystarczy po prostu próba zwerbalizowania (znarratywizowania) przedstawienia, nazwania poszczególnych elementów przedstawionych, odpowiedź na pytanie: o czym jest ten obraz? - czyli swego rodzaju narracja o narracji (lub narracja drugiego stopnia). Innymi słowy - czynnością dokonywaną na źródle ikonograficznym jest o p i s, a więc czynność, jakiej dokonuje na materiale źródłowym uczeń szkoły podstawowej (inaczej: literalne odczytanie źródła).

Kolejna przestrzeń poddawana rozkodowaniu to warstwa perswazyjna (retoryczna). Jako narracja perswazyjna malarstwo (nasze rozważania na temat źródeł ikonograficznych zmierzają do tego właśnie ich rodzaju) i malarz jako twórca tej narracji chce nas do czegoś (o czymś) przekonać. I nie chodzi tu bynajmniej o pokaz kunsztu technicznego, o umiejętności w operowaniu kreską czy plamą barwną (a przynajmniej nie wprost i nie w pierwszym rzędzie, bo jednak i te walory są pomocne dla artysty w jego - jego dzieła - oddziaływaniu). Istotą przekazu obrazowego będzie raczej nakłonienie odbiorcy do, odrzucającego wszelkie wątpliwości, zaakceptowania dzieła jako pewnej bezdyskusyjnej oczywistości. Te przesłanki realizowane są w warstwie widzialnej, czyli informacyjnej, ale umieszczone tam w odpowiedni sposób mogą kreować, zgodnie z koncepcją U. Eco, Czytelnika (Odbiorcę) Naiwnego ${ }^{8}$ (w naszym przypadku Widza Naiwnego). Takich zabiegów retorycznych może być bardzo wiele, dlatego wymieńmy zaledwie niektóre z nich, jak na przykład: rozmiar płótna (lub innego nośnika przedstawienia), kompozycja, oświetlenie, kolorystyka, ale i takie, które wywodzą się od retoryki klasycznej czy teorii literatury: eksklamacja, emfaza, ironia, metafora, alegoria czy różnego rodzaju ramy retoryczne.

Co? (jakie informacje) i jak? (z pomocą jakich zabiegów retorycznych) artysta pokaże w swoim dziele, uzależnione jest od warstwy ostatniej (a w gruncie rzeczy pierwszej i najważniejszej), decydującej o charakterze dwóch pozostałych. Do pięciu głównych, konstytuujących ją elementów, obok języka i jego konwencji, wiedzy ogólnej i faktograficznej, systemu wartości (ideologii) zaliczamy mity (fundamentalne i historiograficzne), bądź szerzej - pe-

${ }^{8} \mathrm{Na}$ temat Eco koncepcji Czytelnika Naiwnego i Krytycznego oraz związanych z nimi $\mathrm{z}$ gadnień, jak intentio auctoris, intentio operis i intentio lectoris, por. m.in. U. Eco, Interpretacja $i$ historia, [w:] Interpretacja i nadinterpretacja, red. J. Culler, przekł. T. Biedroń, Kraków 1996, s. 25-44; idem, Nadinterpretacja tekstów, ibidem, s. 45-65; idem, Lector in fabula. Wspótdziałanie w interpretacji tekstów narracyjnych, przekł. P. Salwa, Warszawa 1994, s. 72 i n. 
wien ich zasób, który możemy nazwać mitologią. Przyjmuję tutaj zsekularyzowane rozumienie mitu ${ }^{9}$, zgodnie z którym w ten sposób określany jest ogół opowiadających o świecie sformułowań, które dzięki siłom społecznym, politycznym lub innym (świadomie) bądź też w sposób żywiołowy istnieją jako nieweryfikowane, unieruchomione i w różnym stopniu zsakralizowane prawdy faktograficzne lub symboliczne, a w ten sposób sformułowane stanowią nierozerwalny element nauki, kultury i ludzkiego myślenia ${ }^{10}$. W kontekście poruszanego zagadnienia definicję tę warto uzupełnić o charakterystykę mitu sformułowaną na gruncie historii literatury, zgodnie z którą używamy terminu mit na oznaczenie idei powstałej w określonych warunkach, jako wyraz społecznego zapotrzebowania, będącej wyobrażeniem, najczęściej fatszywym, o rzeczywistości społecznej, politycznej lub kulturowej. Mit-idea jest dziełem badź klasy społecznej, bądź grupy politycznej, może także być sformułowany przezjednostkę, choć wyraża on $z$ zasady przekonania zbiorowe ${ }^{11}$. Mity historiograficzne, czyli - w odróżnieniu od tzw. mitów fundamentalnych - mniej trwałe, zbudowane z pierwiastków (w różnych proporcjach) niosących konkretne informacje, jak i o charakterze wybitnie perswazyjnym (retorycznym) stanowią nieodłączny element każdej narracji historycznej i ogromnej większości dzieł malarskich. To na nich fundowany jest obraz przeszłości, one, jako wyraz pewnego konsensusu (historyków i artystów, artystów i zamawiających, artystów i odbiorców), tworzą taką, a nie inną wizję dziejów, forsując pewne schematy i uproszczenia i będąc realizacją z góry przyjętej tezy, która zostaje albo zwerbalizowana (historiografia), albo zwizualizowana (sztuka). Rolę ,akuszera" mitów obrazowych (a dotrzymujących z powodzeniem kroku mitom spotykanym w piśmiennictwie historycznym) przejmują dwa rodzaje sił, które $\mathrm{w}$ różnych momentach dziejowych w różnym natężeniu objawiają swą moc.

9 W odróżnieniu od mitu rozumianego w kontekście religioznawczym, który np. M. Eliade definiuje (jak sam zaznacza - szeroko) w sposób następujący: [...] mit opowiada historię święta, opisuje wydarzenie, które miało miejsce w okresie wyjściowym, legendarnym czasie "początków". [...] mit opowiada, w jaki sposób, za sprawa dokonań Istot Nadnaturalnych, zaistniała nasza rzeczywistość; bądź rzeczywistość globalna - Kosmos, bądź tylko jeden jej fragment: wyspa, gatunek rośliny, ludzkie zachowania, instytucja. [...] zawsze jest to opowieść o „stworzeniu”, relacja o tym, jak coś powstało, zaczęło być. [...] mity opisują różnorodne i czasem dramatyczne wtargnięcia sfery sacrum (lub „nad - naturalności”) w obręb Świata. To na tym wtargnięciu ufundowany jest Świat $i$ właśnie za jego sprawa jest on taki, jakim dziś go widzimy, [w:] M. Eliade, Aspekty mitu, przekł. P. Mrówczyński, Warszawa 1998, s. 11.

${ }^{10}$ J. Topolski, Jak się pisze..., s. 204.

11 F. Ziejka, W kręgu mitów polskich, Kraków 1977, s. 8. 
Z jednej strony możemy mówić o siłach „odgórnych”, a więc takich, gdzie siłą napędową dla artysty jest zleceniodawca indywidualny (mecenas/zamawiający/klient) wraz ze swymi zaleceniami, pomysłami i wizją ostatecznego kształtu dzieła. Z drugiej strony - siły „oddolne”, za jakie możemy uznać szeroko pojęte podłoże społeczno-kulturowo-artystyczno-polityczne, lokujące artystę w określonej temporalnie i terytorialnie optyce oczekiwań, których spełnienie staje się często dla niego zadaniem priorytetowym. Przecież większość (jeśli nie wszystkie) dzieł malarskich o tematyce historycznej (i to zarówno tej bieżącej, jak i dawnej w odniesieniu do czasów artysty) lub portretowej służyła, obok chęci utrwalenia jakiegoś ważkiego z różnych punktów widzenia faktu/osoby, przede wszystkim „skomentowaniu” go/jej jako czegoś/kogoś pozytywnego lub negatywnego. A taki komentarz musiał być czytelny dla współczesnego odbiorcy, jeśli bowiem byłby niejasny, nie zostałby zrozumiany, a to z kolei oznaczałoby wykluczenie dzieła (i artysty) z akceptowalnej $\mathrm{w}$ danym momencie dziejowym ikonosfery.

W kontekście naszych rozważań warto w tym miejscu zatrzymać się na chwilę nad trzema funkcjami retoryki klasycznej, realizowanymi przez odwoływanie się do trzech sfer poznania ludzkiego: rozumu (intelektu), woli i uczuć ${ }^{12}$. Należy przy tym zaznaczyć, że pełny (i skuteczny) przekaz retoryczny dzieła będzie zrealizowany dopiero wówczas, gdy spełnione zostaną jednocześnie wszystkie trzy funkcje, choć w odniesieniu do dzieł sztuki (malarstwa) można dokonać pewnych uogólnień i stwierdzić, że w pewnych epokach jedna $\mathrm{z}$ tych zasad brała górę nad innymi ${ }^{13}$. Pierwsza $\mathrm{z}$ nich, docere, to funkcja dydaktyczna sztuki, która ma uczyć (pouczać) przez dostarczanie odbiorcom wiedzy na temat rzeczywistości oraz reguł nią rządzących, inaczej - sztuka winna o tym wszystkim informować. Kolejna, movere, zmierza do poruszenia widza, wstrzą́nięcia nim na tyleż skutecznie, by zechciał przyjąć proponowaną przez artystę wizję, tym samym dając się przekonać do jej słuszności. Ta funkcja w sztuce wiąże się na ogół z epatowaniem widza obrazami (scenami/przedstawieniami) o zabarwieniu zarówno optymistycznym, jak i (i tu być może skuteczniej) pesymistycznym (wywołującym wrażenie niesamowitości, niepewności, lęk, strach, przerażenie czy nawet wstręt. Ostatnie zadanie retoryczne narracji obrazowej, delectare, polega na schle-

${ }_{12}$ M. Bogucka, Sztuka w historii. Kilka refleksji historyka, [w:] Dzieło sztuki: źródto ikonograficzne czy coś więcej? Materiaty sympozjum XVII Powszechnego Zjazdu Historyków w Krakowie, 15-18 września 2004, red. M. Fabiański, s. 12-13.

13 Ibidem. 
bianiu poczuciu estetyki widza, na pozwoleniu mu delektować się dziełem, z którym kontakt będzie dla niego przyjemnością.

Trudno byłoby jednak w przypadku sztuki, będącej odpowiedzią na szersze (społeczne) zapotrzebowanie na określone treści, mówić choćby o możliwości trafienia z nią do każdego, jednostkowego odbiorcy z osobna. Z drugiej strony taka preferowana sztuka istniała, będąc realizacją pewnych ogólnie przyjętych $\mathrm{w}$ danej społeczności uzgodnień światopoglądowych, pewnych bezwarunkowo przyjętych uogólnień dotyczących rzeczywistości, aktualnej i przeszłej. To właśnie te uogólnienia zyskały miano mitów, będących projekcją czasami potrzeb, czasami doświadczeń, zawsze jednak związaną z jakimś tu-i-teraz. Obecność mitów w ikonografii polega przede wszystkim na kultywowaniu pewnych schematów wyobrażeniowych (ikonograficznych, tematycznych), na preferowaniu pewnych wątków przy jednoczesnym pomijaniu innych. I - dodajmy - na konsekwentnym ukazywaniu w danym momencie historycznym tego, co ukazywane być powinno. Takich mitów, w szczególności zakorzenionych w malarstwie polskim, było wiele i każda epoka obrastała w coraz to inne, nowe mityczne dogmaty, tworząc, z dzisiejszej perspektywy, wielką, ikonograficzną mitologię. Właściwie ten zbiór mitów obrazowych koresponduje ze zbiorem mitów historiograficznych, unieruchomionych w pisarstwie historycznym. Możemy zatem mówić o micie walk powstańczych, o ściśle związanym z nim micie mesjanizmu ${ }^{14}$, martyrologii i posłannictwa narodu polskiego, czy o micie dotyczącym roli chłopów ${ }^{15}$. Jerzy Ronikier, śledząc zagadnienie mitotwórstwa $\mathrm{w}$ podręcznikach szkolnych do historii, odnajduje w nich dodatkowo pewne mity, które również możemy spotkać wśród płócien zdobiących ściany sal muzealnych ${ }^{16}$ : mit dobrego króla, mit piastowski ${ }^{17}$, mit państwa (w tym mit prapoczątku), mit narodu polskiego $^{18}$. Tę mitologię możemy poszerzyć o mit Napoleona oraz mit rycerza-

${ }_{14}$ Por. M. Siwiec, Mit mesjaństwa polskiego narodu wybranego, [w:] Mity. Historia i struktura mistyfikacji, red. Z. Drozdowicz, Poznań 1997, s. 111-124.

${ }_{15}$ Ten ostatni będący realizacją postulatu walki o „wyzwolenie polityczne” w połączeniu z walką o „wyzwolenie społeczne”. Te rodzaje mitów przytaczam za J. Topolski, Jak się pisze..., s. 276-291. s. $74-142$.

${ }^{16}$ J. Ronikier, Mit i historia. Mitotwórcze funkcje podręczników szkolnych, Kraków 2002,

${ }_{17}$ Por. też: M. Kosman, Mity w polskiej literaturze historycznej, [w:] Mity. Historia i struktura..., s. $102 \mathrm{i} \mathrm{n.}$

18 Por. też: Z. Drozdowicz, Mit narodu polskiego, [w:] Mity. Historia i struktura..., s. 125-133 . 
-Sarmaty. Jak widać, mitologia tematyczna przedstawień obrazowych płynie równolegle z prądem mitów obecnych w historiografii, jak i w prozie czy dramacie. Przyobleka się tylko w inne artystycznie szaty. Jest zarazem odpowiedzią (odbiciem wręcz) nastrojów społecznych czy określonego światopoglądu. Istotny jest także fakt, że historia ilustrowana dziełami malarstwa to przede wszystkim - w odniesieniu do malarstwa historycznego (batalistycznego) momenty wielkie, ważkie, przełomowe i najczęściej jako takie traktowane po dzień dzisiejszy, przynajmniej przez większość społeczeństwa.

Rozmaite mity, które, bardziej lub mniej zakamuflowane, przebijają się przez tkankę malarstwa, stoją z kolei u źródeł kreowania stereotypów, czyli wytworów świadomości, zawierających w sobie często ślad mitu, lecz odpowiednio zracjonalizowanego. Ta racjonalizacja zaś wynika z faktu, że stereotypy podlegają przede wszystkim celom pragmatycznym, czyli głównie służą usprawiedliwianiu różnorodnych społecznych postępowań według schematu „czarne-białe”, który to schemat czerpany jest z bogatego zaplecza wartości lub pseudowartości traktowanych jako dostatecznie zrozumiałe, powszechnie dostępne i jednoznacznie zdefiniowane ${ }^{19}$. Jasnym się staje, że stereotyp w kontekście dzieł malarstwa będzie przyjmował postać najpierw pewnych schematów ikonograficznych, pewnych układów kompozycyjnych, pewnego powtarzającego się sposobu ukazywania postaci lub wydarzenia, ewokującego pożądany efekt i ocenę, a w końcu - wydostawszy się jakoby „poza” dzieło - pewnego obrazu zagnieżdżonego w zbiorowej świadomości. Wystarczy podać przykład banalny: nie sposób sobie często wyobrazić jakiejś postaci (choćby któregoś z polskich władców) czy wydarzenia (Hołd pruski) bez nachalnie cisnącego się skojarzenia z konkretnymi przedstawieniami obrazowymi (w wymienionych przypadkach - pędzla Matejki). I te schematy (w tym bardzo często uogólniane; spotykamy przecież tzw. stereotyp Żyda, stereotyp Niemca czy stereotyp polskiego powstańca), uznawane drogą powszechnego konsensusu za oczywiste i bezdyskusyjne, uniezależniając się od swych twórców, wiodą sobie spokojny żywot wśród przeciwników „odcieni szarości”20. Mieczysław Porębski, nie bez ironii, wyodrębnił kilka takich trwałych, i do

${ }_{19}$ M. Janion, Polski korowód, [w:] Mity i stereotypy $w$ dziejach Polski, red. J. Tazbir, Warszawa 1991, s. 188.

${ }^{20} \mathrm{Na}$ temat stereotypów por. m.in.: Z. Bokszański, Stereotypy a kultura, Wrocław 1997; J. Berting, Ch. Villain-Gandossi, Rola i znaczenie stereotypów narodowych w stosunkach międzynarodowych: podejście interdyscyplinarne, przekł. J. Piątkowska, [w:] Narody i stereotypy, red. T. Walas, Kraków 1995, s. 13-27; T. Szarata, Niemiecki Michel. Dzieje narodowego symbolu i autoste- 
dziś pokutujących w powszechnej/potocznej świadomości, stereotypów obrazowych, które pozwolę sobie zacytować:

Jeździec rzucajacy się z koniem do wody: „Bóg mi powierzyt honor Polaków”. [Poniatowski, Elstera - przyp. JB];

Młodzieniec jedna ręka obejmujacy czcigodnego starca, a druga odsuwajacy ofiarowywane mu insygnia władzy: Leszek Biaty i Goworek; "Nad blask, co berto udziela, wyżej cenię przyjaciela";

Postać pótleżaca na tle bitwy: Śmierć X-a pod N.;

Rycerz rzucający dumnym gestem pierścień do skrzyni petnej złota: Habdank; "Idź ztoto do ztota, my Polacy... ”;

Armaty i kosynierzy: Ractawice;

Przedstawiciele któregoś z państw ościennych klęcza, król polski siedzi: Hołd pruski, Batory pod Pskowem itp. ${ }^{21}$

I wreszcie pora na trzecie, zasygnalizowane w tytule pojęcie - fantazmat. Nie jest to pojęcie, które pojawia się w pracach dotyczących narracji historycznej, ale w świetle źródeł ikonograficznych sięgnięcie do niego wydaje się uprawomocnione (czy wręcz konieczne). Jego rozumienie przyjmuję również za Marią Janion, która, choć przyznaje się do inspiracji psychoanalitycznym, Freudowskim znaczeniem fantazmatu ${ }^{22}$, proponuje definicję „luźniejszą”, pod którą ukrywają się różne fantazje, iluzje, urojenia, marzenia i mistyfikacje, charakteryzujące się wyraźną strukturą dramatyczną, literacką i fabularną, a pełniące funkcję teatralizacji życia wewnętrznego i zewnętrznego; takie, jak pisze dalej badaczka, uruchomienie wyobrażeń (nazywa ten akt teatrem duszy oraz chwilowa inscenizacja pragnień) stanowi sedno „maszynerii” pewnego typu literatury, tkwiącej korzeniami w folklorze literatury popularnej oraz kształtowanej przez nią potocznej (zbiorowej) wyobraźni ${ }^{23}$.

reotypy, Warszawa 1988; W. Wrzesiński, Sąsiad czy wróg. Ze studiów nad kształtowaniem obrazu Niemca w Polsce 1795-1939, Wrocław 1992.

${ }_{21}$ M. Porębski, Malowane dzieje, Warszawa 1961, s. 186.

22 Definiowanego jako coś w rodzaju wyobrażonego (wyimaginowanego) przez kogoś scenariusza, w którym spełniane są jego życzenia, natomiast to wszystko, co dana osoba uznaje za autentyczne wspomnienia, okazuje się jedynie fantazją; nigdy nie miało miejsca lub przebiegało w sposób odmienny.

${ }^{23}$ M. Janion, Polski korowód..., s. 188. Pojęciem fantazmatu w kontekście analizy tytułowej postaci z obrazu Matejki Dziewica Orleańska posługuje się również I. Kowalczyk, por. eadem, Dziewica Orleańska Jana Matejki - konstrukcja, legenda, transgresja..., „Artmix. Sztuka - Feminizm - Kultura wizualna”, nr 3, styczeń-czerwiec 2002, http://free.art.pl/artmix/archiw_3/0102ik.html (dostęp: 27.03.2012). 
Sadowiąc swe rozważania w epoce romantyzmu badaczka w ten oto sposób konkretyzuje swoje rozumienie fantazmatu:

Mówiąc uczenie, fantazmat jest derywatem marzenia, które najczęściej odwołuje się do wyrazistego dualizmu kontrastów, tak charakterystycznego dla romantyzmu. Marzenie romantyczne przeciwstawia sobie dwa miejsca bytowania i dwie rzeczywistości. Czyni to na dodatek w trybie wartościującym. Lepsze jest „tam”, gorsze jest „tutaj”. Dlatego romantyczny marzący jest tam, gdzie go nie ma, a nie ma go tu, gdzie jest. Z powodu tego rodzaju bytowania niepodobna nie zastanowić się nad osobliwym kryzysem tożsamości, występującym często u romantycznego marzyciela. Goni on za coraz to nowym przebraniem, nową maską, nowym kostiumem. [...] Fantazmaty wynikają właśnie z tej postawy i żywią się nią. [...] Fantazmat zaś jako maska i jako kostium musi stać się przedmiotem humanistycznych rozmyślań24

Owo uruchomienie wyobraźni, przejawiające się wprowadzaniem w świat przedstawień malarskich elementów, nazwijmy je, „życzeniowych”, pojawia się również w twórczości tych artystów, którzy niczym Freudowskie marzenia dzienne snują swe romantyczne i poromantyczne wizje świadomie, krystalizując je na płótnach/kartonach pod postaciami somnambulicznych korowodów ${ }^{25}$ czy androgynicznych Thanatosów ${ }^{26}$, jako pochody „truposzów” lub pod postacią wywodzących się z różnorodnych mitologii stworzeń ${ }^{27}$. Ludowość i folklor z jednej, a mitologia chrześcijańska do spółki z pogańską z drugiej strony, to faktyczne źródła tego typu (wizyjno-fantastyczno-literackich) przedstawień, w szczególności związanych z romantyzmem i symbolizmem, w których ze szczególną mocą spełniają się dwie (movere i docere) funkcje retoryczne obrazu. Poprzez pewną niejasność, niejednoznaczność, tajemniczość, nie zawsze operując „pięknymi” formami, trafiają do widza właśnie oferując cały wachlarz środ-

${ }^{24}$ M. Janion, Projekt krytyki fantazmatycznej, [w:] Prace wybrane, t. 3: Zto i fantazmaty, Kraków 2001, s. 163.

${ }_{25}$ Np. obraz Teofila Kwiatkowskiego Polonez Chopina (Bal w Hotelu Lambert w Paryżu), 1849-1860, Muzeum Narodowe, Poznań; reprodukcja: http://www.mnp.art.pl/muzeum/oddzialy/galeria-malarstwa-i-rzezby/galerie / galeria-sztuki-polskiej-od-konca-xviii-do-1945-roku/ galeria-zdjec.

${ }^{26}$ Jacek Malczewski, Thanatos, 1898, Muzeum Narodowe, Poznań, http://www.pinakoteka.zascianek.pl / Malczewski_J/Images/Thanatos_I.jpg.

${ }^{27}$ Jacek Malczewski, Madonna, ok. 1910, Muzeum Narodowe, Poznań, http://www.pinakoteka.zascianek.pl/ Malczewski_J/Images/Madonna.jpg. 
ków/motywów z ikonosfery symboli, gdzie nic, a przynajmniej większość, nie jest tym, czym wydaje się być; lub dokładniej - pod warstwą widzialną ukryta jest druga, niewidzialna, która dopiero stanowi o sensie i przesłaniu dzieła.

\section{Mitologie i fantasmagorie Witolda Pruszkowskiego}

Przywołane przed momentem pochody truposzów posłużyły jako swoisty pretekst do przywołania wielkiego nieobecnego w podręcznikach szkolnych (i na lekcji historii w ogóle) polskiego artysty, spóźnionego romantyka i prekursora nastrojowego/wizyjnego symbolizmu - Witolda Pruszkowskiego (1846$-1896)^{28}$. Absolwent Akademii Monachijskiej, uczeń Jana Matejki (od którego jednak oddalił się dzięki wizyjności swych obrazów) i przyjaciel Jacka Malczewskiego (do którego zbliża go właśnie ów symbolizm) pozostawił wśród swego artystycznego oeuvre liczne portrety, dzieła rodzajowe obrazujące proste lecz pełne uroku życie chłopów, niejednokrotnie gęsto przetykane pierwiastkami baśniowymi czy legendarnymi bądź w pełni zanurzone w ludowych podaniach, tajemnicy i świecie splatającym wątki ziemskie i pozaziemskie $^{29}$. Według Ewy Micke-Broniarek

istoty nadprzyrodzone - rusałki, nimfy, uskrzydlony smok - zaludniające te baśniowe krajobrazy zazwyczaj przybierają zdumiewająco cielesną, niekiedy kusząco zmysłową postać, odtwarzaną z zachowaniem reguł realistycznego obrazowania. Dopiero w późniejszych dziełach artysty postacie fantastyczne ukazywane są bardziej zjawiskowo, nie tak dosłownie i materialnie ${ }^{30}$.

Odwołanie do tych dzieł Pruszkowskiego jest niezbędne w kontekście innego nurtu w jego twórczości, przy którym, jako kluczowym dla niniejszego artykułu, chciałabym się zatrzymać na dłużej. Jest to bowiem nurt pod względem czasowym równoległy do przywołanego powyżej i dzielący wraz z nim wizyjno-fantastyczny charakter, ale osadzony w zupełnie odmiennej

${ }_{28}$ M. Gołąb, A. Ławniczakowa, M. P. Michałowski, Galeria Rogalińska Edwarda Raczyńskiego, Poznań 1997, s. 168.

${ }^{29}$ M.in. Kiedy ranne wstaja zorze, 1876, Muzeum Narodowe, Warszawa; Rusatki (Nimfy wodne), 1877, Muzeum Narodowe, Kraków; Zaduszki, 1888, Muzeum Narodowe, Warszawa.

${ }^{30}$ Ewa Micke-Broniarek, Witold Pruszkowski, http://www.culture.pl/baza-sztuki-pelnatresc/-/eo_event_asset_publisher/eAN5/content/witold-pruszkowski (dostęp: 30.03.2012). 
tematyce patriotyczno-martyrologiczno-mesjanistycznej. To właśnie dzieła zogniskowane wokół tych idei wydają się na tyle interesujące pod względem źródłowym/poznawczym, że pozwalają na, z jednej strony - analizę i interpretację porównawczą z innymi przekazami (wchodząc $\mathrm{w}$ dialog zarówno z innymi źródłami ikonograficznymi, jak i, co zostanie za chwilę uwidocznione, ze źródłami literackimi), z drugiej zaś - są trudnym do przecenienia przykładem mitologizacji/stereotypizacji i fantazmagoryzowania historii.

Nie miejsce tu na systematyczne omówienie mitologii Pruszkowskiego, dlatego też posłużę się jednym, lecz reprezentatywnym w kontekście tematu przykładem zaangażowania artysty w nurt historii mitycznej, wskazując jednocześnie na historii tej inność i swoistość.

Na dalekim Uralu, w pobliżu linii kolejowej, którą przejeżdża Ekspres Transsyberyjski z Moskwy do Władywostoku, we wsi Rieszoty wznosi się kamienny obelisk o dwu drogowskazach. Jeden z nich z napisem „Europa” zwrócony jest na zachód, drugi z napisem „Azja” wskazuje wschód. Obelisk ów przez dziesiątki lat był milczącym świadkiem pożegnań rozstających się z bliskimi zesłańców, wędrujących do odległych często miejsc w Azji, skazanych na katorgę lub zesłanie. Był też widomym znakiem granicznym ich dotychczasowych praw, a także języka, religii i obyczajów, jednym słowem - wpływów kultury europejskiej. Syberia, ta odległa, położona na wschód od Uralu kraina Rosji, ze względu na niedostatek zwykłych dróg i brak jakichkolwiek połączeń kolejowych, stała się dla caratu idealnym miejscem odosobnienia jeńców wojennych, działaczy politycznych oraz odbywania kary przez pospolitych przestępców ${ }^{31}$.

Polski powstaniec (insurekcja kościuszkowska, powstanie listopadowe czy styczniowe) to w świetle powstańczej ikonografii przede wszystkim, jak trafnie skądinąd określił Jerzy W. Borejsza, krakuski, konie, sukmany, kosy, ewentualnie szabla, kosa, krzyż, koń ${ }^{32}$. Ale to również obrazowe losy zesłańców (wraz z całym dramatyzmem sytuacyjnym), najczęściej w drodze do jakiegoś złowrogiego tam, bo tutaj zabrakło dla nich miejsca. Wątek rodzajowy

${ }^{31}$ M. Szczęsny-Mrówczyńska, Pamiętnik malarski Aleksandra Sochaczewskiego, „Wiedza i Życie” 1996, nr 1, wersja elektroniczna: http://archiwum.wiz.pl/1996/96013100.asp (dostęp: $1.04 .2012)$

${ }^{32} \mathrm{~J}$. W. Borejsza, Wokót stereotypu polskiego powstańca, [w:] Mity i stereotypy $w$ dziejach Polski, red. J. Tazbir, Warszawa 1991, s. 247, 248. 
(bo tak chyba należałoby go kwalifikować), unurzany wszakże w martyrologii, ukazuje zazwyczaj z całą, rzeczywistą bądź uwznioślającą mocą, tragizm i dramat (czasami z patosem, kiedy indziej znowu na wskroś naturalistycznie $^{33}$ ) zesłania. Wróćmy jednak do owego kamiennego obelisku (bądź czasami po prostu słupa granicznego). To także jeden z chętnie wykorzystywanych w malarstwie motywów, jawiący się jako swego rodzaju Rubikon, którego przekroczenie jest z jednej strony symbolicznym, ale przecież z drugiej - dosłownym rytuałem przejścia dla zesłańców. To niejako ostatni etap tułaczki, ostateczne porzucenie w gruncie rzeczy oswojonego tu-i-teraz na rzecz obcego i złowrogiego tam-i- (dla wielu) na zawsze. Ten moment przejścia odnajdujemy również u Pruszkowskiego, w obrazie Na zestanie w Sybir (ok. 1893) ${ }^{34}$. Uczucie dojmującej pustki wywołane wielkimi połaciami pokrytej śniegiem krainy, wschodzące słońce (paradoks? ironia losu?) rozświetlające dominujące nad pustkowiem niebo, majaczące gdzieś w głębi zamarznięte kikuty drzew - i pośród tego wszystkiego oddalająca się od widza grupka pochylonych postaci w szynelach, bardzo widmowych w stosunku do znajdującego się na pierwszym planie słupa granicznego zwieńczonego carskim orłem. Jako swoisty dialog międzyobrazowy przywołajmy w sukurs rysunkowe Zestanie na Sybir Artura Grottgera (1867) ${ }^{35}$. I tu spotykamy słup, śnieg, groźnie tym razem skłębione chmury ponad sceną. Na tym jednak podobieństwa się kończą. Grupa zesłańców stoi spokojnie i (tylko przez kontrast do obrazu Pruszkowskiego) na swój sposób dumnie, widzimy tylko jedną omdlewającą postać mężczyzny na pierwszym planie, wspierającego głowę na udzie swego towarzysza. A jednak ta kompozycja, mimo swej horyzontalności, nie jest spokojna. Gwałtowny gest Rosjanina na koniu, psy oszczekujące zesłańców, chaotyczne ślady stóp na śniegu - to wszystko nie ma w sobie takiego ładunku beznadziei i melancholii jak pierwsze z przytoczonych przedstawień. Swoistość redakcji tematu pędzla Pruszkowskiego uwydatni się z jeszcze większą mocą, gdy zestawimy ją z Pożegnaniem z Eu-

33 Przykład takich redakcji tematu to choćby wersje Śmierci Ellenai pędzla J. Malczewskiego (Pruszkowski także poświęcił poematowi Słowackiego kilka swych, rzecz jasna - utrzymanych w niesamowito-onirycznej atmosferze - obrazów), lub wcześniejsze, również jego autorstwa (z okresu przedsymbolicznego) naturalistyczno-reporterskie migawki z drogi na Sybir i pobytu tamże (np. Śmierć na etapie, Wigilia na Syberii).

${ }^{34}$ Lwowska Galeria Sztuki, http://www.pinakoteka.zascianek.pl/Pruszkowski_W/Images/Na_zeslanie.jpg.

${ }_{35}$ Muzeum Narodowe, Poznań, http://www.pinakoteka.zascianek.pl/Grottger/Images/ Pochod.jpg. 
ropa Aleksandra Sochaczewskiego (1894) ${ }^{36}$. Tym razem obelisk przesunięto na plan dalszy, pierwszy plan wypełniając tułaczą rodzajowością. Zesłańcy (wśród nich kobiety) zebrani w kilkuosobowe grupy lamentują, siedząc bezradnie na śniegu, podczas gdy jeden z nich dotyka w głębi obelisku w geście pożegnania. Podobnie jak u Grottgera unaoczniono tutaj moment przed przekroczeniem granicy (symbolicznej granicy między życiem a śmiercia), a efekt ekspresyjny tworzy takaż mimika i gestykulacja postaci.

A jednak wizja Pruszkowskiego ma chyba największy ładunek emocjonalny. Czy feruje mit? Z pewnością. Czy upowszechnia stereotyp? Bez wątpienia. Co więcej - sytuuje się niejako na granicy pomiędzy mitem/stereotypem a fantazmatem (o którym za chwilę). Z tą wszakże różnicą, że tutaj jest $z \nmid e$, a tam - jeszcze gorsze...

Gdzie zatem szukać fantazmatu ex definitione? Również u Pruszkowskiego. Hołubiąc romantycznej wykładni „narodu wybranego” i wplatając wątek Matki Boskiej Orędowniczki Narodu Polskiego/Królowej Polski stworzył Pruszkowski obraz zatytułowany Wizja $(1890)^{37}$. To tu wreszcie pojawiają się zasygnalizowane wcześniej truposze, wskrzeszone wizją artysty grając (znowu) swe role, choć w innym nieco od pierwotnego kontekście. Obraz jest w zasadzie wierną ilustracją Przedświtu Zygmunta Krasińskiego, aplikującą swą tajemniczą i oniryczną poetykę na i tak już fantasmagoryczną wizję poety. Co możemy zobaczyć w malarskiej wersji? Oddajmy głos Krasińskiemu, który uczytelni nie do końca jasny na pierwszy rzut oka obraz:

Przebóg, siostro, co się dzieje? Złote gwiazdy na jej łonie;

To nie wiatru szum tak wieje! Czy poznajesz ty, kto ona?

Ktoś tam zcicha płacze, wzdycha, Witaj, witaj! - To Królowa,

$\mathrm{Z}$ nad wybrzeży jęk się szerzy; Po swym ludu długo wdowa,

W nocnym wietrze przez powietrze I dziś wraca w tej koronie,

Tysiąc jęków do nas bieży. Którą w polskiej Częstochowie Już brzeg cały, wzgórza, skały, Niegdyś dali Jej ojcowie,

Brzmią modlitwy głuchej kołem.

I tych ojców przez te tonie,

Wielki Boże! Czy być może? Patrz, prowadzi!

Duchy ojców tu ściągnąłem! Nie graj więcej!

${ }^{36}$ Muzeum Niepodległości, Warszawa, http://artyzm.com/obraz.php?id=2969.

${ }_{37}$ Muzeum Narodowe, Poznań, http://www.mnp.art.pl/fileadmin/pliki/MNP/GMiR/galeria_sztuki_polskiej_do_1945/Pruszkowski_-_Wizja.jpg. 
Za wodami - tam, przed nami, $\mathrm{Z}$ fal tych drugiej takiej tęczy

Jak sny lekkie, lekką zgrają Nasza harfa nie wydźwięczy,

$\mathrm{Na}$ opokach się wieszają; Ni te Duchy tu przynęci!

Jak płomyki, jak ogniki, Już ich tchnęło światło boże

To się wznoszą, to znżeają...

I gdzieś spieszą - zbrojnie - skoro.

Do strun, siostro! Uderz w struny! Złotem wokół szklni jezioro,

By ich łacniej pieśń zaklęła, $\mathrm{Na}$ ich hełmach błyska zorze;

W akordowe graj pioruny,

W dawnym polskich bitew stroju,

Graj im: „Jeszcze nie zginęła!”... Przebóstwieni, rozzłoceni,

Harfa, głosem, płacz, proś, szalej! Jakby znowu szli do boju!

Pieśn rodzinna tu powinna Srebrne skrzydła, w zbroję wtknięte

Przyprowadzić ich z oddali! Im z nad ramion wgórę lecą,

Widzisz, widzisz: - usłyszeli! Turkusami zbroje spięte,

$\mathrm{Na}$ ciemnościach tacy bieli

Z żywej stali rękawice,

Z skał spływają już do brzegu... Strusie pióra wyżej głowy

Ot, w powietrznym już pochodzie Jak olbrzymie słupy śniegu. [...]

Po tej czarnej kroczą wodzie,

I dobyte do połowy

Przewodowo - zwolna - święcie Damasceńskie ich szablice.

Przez to dźwięków rozbłyśnięcie Każden oczy ma wzniesione,

Idą, idą wszystkie mary. W przeanielską patrzy Panią,

Patrzał, patrzał: w dziwnej chwale, I po falach stąpa za Nią

Wszyscy z trumien polskich rodem, W nieskończona jakąś stronę;

Idą, idą przez te fale I miecz dławi w swej prawicy

Chrystusowym do nas chodem! Wyżej serca, na zbroicy,

Tam buńczuki, tam sztandary, Jakby miał się ku obronie

Śnieżne pióra i korony, Tej, lecącej w gwiazd koronie.

Katolicki krzyż wzniesiony; A Królowa ta nie z ziemi,

Wkoło herby, tarcze, znaki Jak sen, wije się przed niemi

I tłum szabel, i szyszaki. Coraz dalej...

Przeciagają - patrz, tam żywa Pani, Pani!

Twarz z powietrza się wyrywa, Wszak z pomarłem sług plemieniem

Twarz - czy widzisz? - Anielicy Ty zstępujesz do otchłani

Jak gwiazdeczka na ciemnicy, Po raz drugi zdeptać węża! [...] 
W górze, w górze zawieszona, Wiem już teraz, o ojcowie, Wschodzi-weszła- tli-drga- płonie... Gdzie z Królową tą w szkarłacie

Ot, z błękitów i szkarłatów Tak spieszycie, przemijacie!

Już otęcza ją przesłona, Ale czyjże głos mi powie,

Na tle z pereł, na tle z kwiatów, Kiedy nazad z tej oddali

Diamentowa lśni korona... Na tę ziemię powrócicie,

W krzyż na piersiach zwite dłonie, By i żywi w złotym świcie

$Z$ letargowych trumien wstali? [... $]^{38}$

Odczytanie obrazu w świetle poematu Krasińskiego pozwala na wyciągnięcie istotnego wniosku, dotyczącego wykorzystania tego rodzaju źródeł na lekcji historii. Pozwoli mianowicie umocować przedstawienie w szerszym, historiozoficznym kontekście epoki, do której się odwołuje (a więc do filozoficznego i mentalnego zaplecza romantyzmu). Poprzez próbę opisu i nazwania wyodrębnionych w tekście postaci i atrybutów możliwe będzie dotarcie do specyficznego kodu, jakim operowali artyści (ale nie tylko) romantyczni próbując nadać sens (choćby najbardziej życzeniowy) temu, co ofiarowała im historia. To właśnie takie fantasmagoryczne wizje, jak Pruszkowskiego i Krasińskiego, oscylujące pomiędzy dwoma porządkami, dwoma światami, tym niedoskonałym/doczesnym i doskonałym/przyszłym/boskim dawały asumpt swym XIX-wiecznym odbiorcom (widzom i czytelnikom) do tego, aby nie tracili nadziei i spoglądali właśnie w owe zaświaty czy też międzyświaty, gdzie można odnaleźć głębsze/inne sensy i znaczenia.

\section{Zakończenie}

Zasygnalizowane w tytule niniejszego artykułu pojęcia szablon i inna wizja przeszłości wbrew pozorom nie wykluczają się, co więcej - owa inność wywodzi się wprost z ogromnego zbioru historii zmitologizowanych i stereotypowych. Podjęłam próbę może nie tyle odczarowania mitów (a właściwie podejścia do nich), stwierdziwszy daremność i w gruncie rzeczy brak zasadności takiego postępowania, ile spróbowałam zaczarować właśnie owe inne wizje historii, które chyba są spychane na margines w aspekcie źródłowym/po-

38 Z. Krasiński, Przedświt. Z portretem poety i 5-oma rycinami, oprac. B. Suchodolski, Warszawa 1929, s. 38-43, www.pbi.edu.pl (dostęp: 20.06.2007); wytłuszczenia autorki. 
znawczym. Przy czym zaznaczyć należy wyraźnie, że pod pojęciem inne nie należy rozumieć alternatywne, lecz raczej jako równolegle do „oficjalnych”, „uznanych”, „pewnych” i „bezpiecznych” snute narracje obrazowe. Odwołujące się, co również należy podkreślić, bardzo silnie do emocji i pewnej intuicji, do subiektywizmu i woli poznawczej zainteresowanego - co odróżnia je od tych pierwszych i może, przy ostrożnym podejściu, okazać się atutem. W zasadzie źródło informacji w szkole możemy przyrównać do hipertekstu. Każde źródło bowiem, przy odrobinie dobrej woli ze strony jego odbiorcy, oferuje pewne mniej lub bardziej zakamuflowane odsyłacze poza siebie, do innych obrazów, tekstów i opowieści.

\section{Myth, stereotype and phantasm - between the template and other vision of the past in a school history course (the iconography case) \\ (Summary)}

The article is an attempt to guide a reader from the guidelines included in the standards/requirements of the examination for the upper secondary school, relating to work with different types of information sources, through the three interpretative spaces of a pictures, with which a pupil is being acquainted during the three educational stages, to - finally - specific iconographical sources, representing the mythical, stereotyped and phantasmatic evocation of the past. The title versions of the past reality: template (myth and stereotype) and other (phantasm), found in the selected works of Witold Pruszkowski, are not alternative to each other. They are rather the pictorial narratives running parallel, although requiring a slightly different approach and equipment from the interpreter.

Justyna Budzińska,

Instytut Historii, Uniwersytet im. Adama Mickiewicza e-mail: jbudzinska@poczta.onet.pl 